\title{
Morphological variation of Stephanodiscus niagarae Ehrenb. (Bacillariophyta) in a Lake Ontario sediment core
}

\author{
Eugene F. Stoermer, ${ }^{1}$ Gail Emmert ${ }^{1}$ \& Claire L. Schelske ${ }^{2}$ \\ ${ }^{1}$ Center for Great Lakes and Aquatic Sciences, University of Michigan, Ann Arbor, MI 48109 USA; \\ ${ }^{2}$ Department of Fisheries and Aquaculture, University of Florida, Gainesville, FL 32606 USA
}

Received 3 January 1989; accepted 5 April 1989

Key words: Stephanodiscus, diatom, eutrophication, morphology, core, sediments

\begin{abstract}
Stephanodiscus niagarae populations in a core from Lake Ontario show systematic variation in radial puncta number and mean valve diameter. Puncta number is stable in specimens from samples deposited between 1720 and 1844. Puncta number gradually increases in samples deposited between 1860 and 1947 , then increases rapidly to high numbers in samples deposited after 1964. Mean valve diameter is relatively high in specimens from samples deposited between 1720 and 1959. Diameter of specimens deposited during this period fluctuates around a mean of $63.2 \mu \mathrm{m}$. Mean diameter of specimens deposited from 1959 to 1980 is only $42.5 \mu \mathrm{m}$. We conclude that the trend in puncta number reflects the time course of eutrophication in Lake Ontario. We interpret the precipitous decline in mean diameter as an indication that conditions in the lake after the late 1950's did not permit sexual reproduction in this species.
\end{abstract}

\section{Introduction}

Stephanodiscus niagarae Ehrenb. is a large and conspicuous member of the genus. Although distribution records are difficult to address, since it is one of the species commonly reported under the illegitimate epithet ' $S$. astraea' (Håkansson \& Locker, 1981), it is widely distributed in North America (Theriot \& Stoermer, 1984a). It is also present in interglacial deposits from Asia (Theriot et al., 1988) and Europe (Cleve-Euler, 1951), although reports of modern occurrences outside North America are scarce and need verification.

North American populations are highly variable. As is the case in other Stephanodiscus species (Genkal \& Kuzmin, 1979), rotational elements of the valve (e.g. fascicles, interfascicles, spines) commonly used as taxonomic characteristics, are reduced during size reduction resulting from asexual reproduction. Valve morphology is also affected by ecological conditions (Theriot \&
Stoermer, 1984a), with populations from eutrophic habitats having more closely spaced puncta and radial ribs. Quantification of these relationships has led to recognition of new varieties (Theriot \& Stoermer, 1986) and closely related species (Theriot \& Stoermer, 1984b).

Here we report on the time course of morphological variation in $S$. niagarae during the recent history of Lake Ontario. The species was originally described from the vicinity of Niagara Falls (Ehrenberg, 1846). Stoermer et al. (1985a) reported that it is one of few species consistently present in Lake Ontario sediments deposited during the period from ca. 1720 to 1980 . Stoermer et al. (1985a) interpreted changes in the diatom flora during this period as evidence of eutrophication. According to their interpretation, significant eutrophication began soon following largescale European settlement of the area (ca. 1830) and Lake Ontario became grossly eutrophied after ca. 1950. This sequence of ecological 


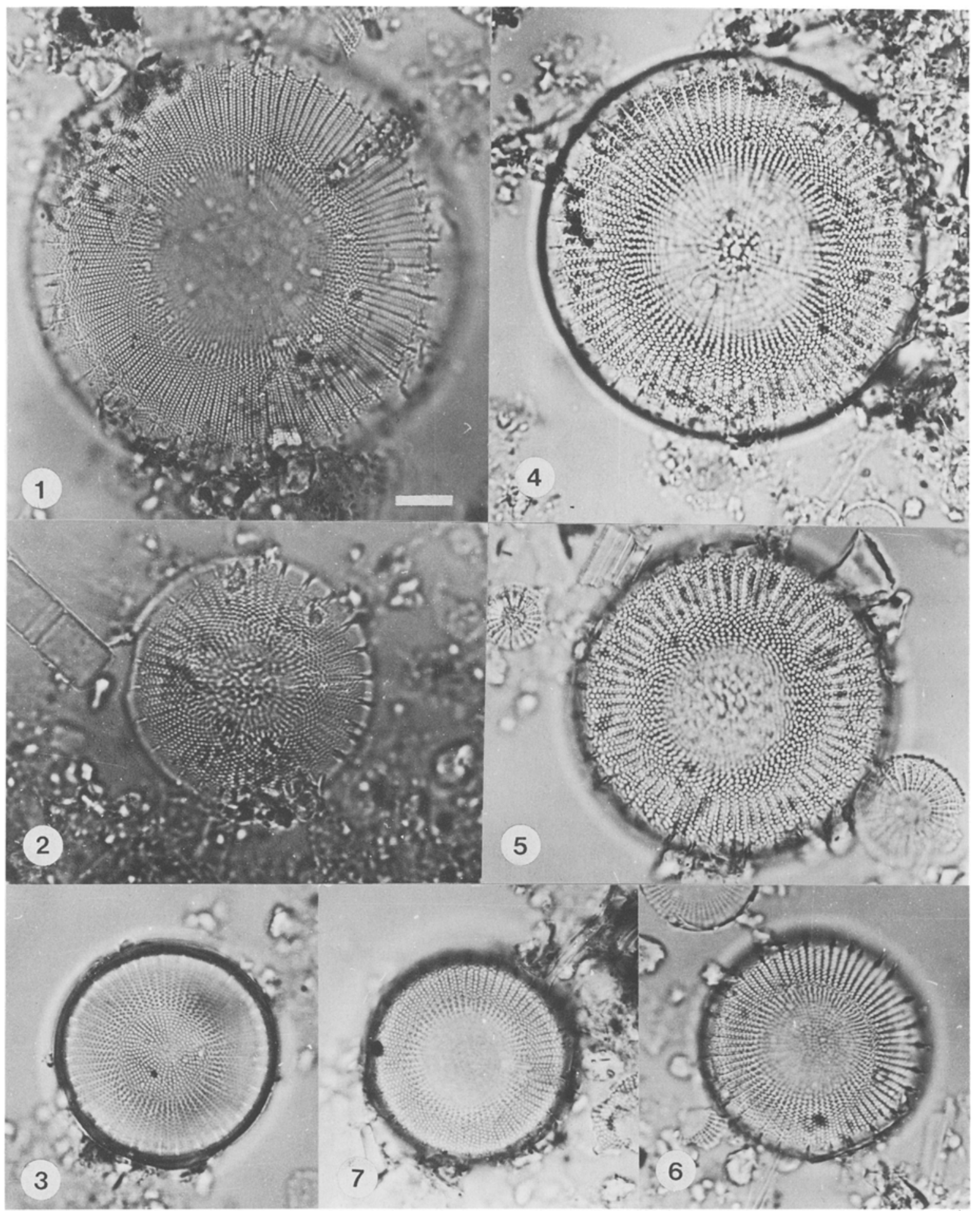

Figs. 1-7. Stephanodiscus niagarae from Lake Ontario sediments. Scale bar equals $10 \mu \mathrm{m}$ for all Figs. Fig. 1. Large, finely structured valve from 6-7 cm depth stratum. Note abnormal fascicle structure in upper and lower segments of valve. Fig. 2. Valve with fine puncta structure from 5-6 cm depth stratum. Fig. 3. Small valve with fine puncta structure from 0-1 depth stratum. Fig. 4. Large valve with coarse puncta structure from $30-32 \mathrm{~cm}$ depth stratum. Fig. 5. Mid-sized valve with coarse structure from $38-40 \mathrm{~cm}$ depth stratum. Fig. 6 . Valve with intermediate puncta structure from $6-7 \mathrm{~cm}$ depth stratum. Fig. 7 . Valve with intermediate puncta structure from $5-6 \mathrm{~cm}$ depth stratum. 
perturbation is also reflected by modification of puncta structure in Melosira islandica O. Müll. (Stoermer et al., 1985b).

\section{Materials and methods}

Material studied comes from a core (E30-RNB-1) taken by Dr. R. A. Bourbonniere, Canada Centre for Inland Waters, Burlington, Ontario, Canada, on 8 May 1981 . The coring site $\left(43^{\circ} 30.2^{\prime} \mathrm{N}\right.$; $76^{\circ} 54.1^{\prime} \mathrm{W}$ ) is in an offshore depositional basin.

The core was sectioned at $1 \mathrm{~cm}$ intervals to $20 \mathrm{~cm}$ and at $2 \mathrm{~cm}$ intervals thereafter. Total length of the core was $40 \mathrm{~cm}$. Each section was homogenized and then freeze-dried to permit accurate dry weight measurements without problems of compaction and microfossil breakage resulting from air drying.

For siliceous microfossil analysis material was cleaned by oxidation in $\mathrm{H}_{2} \mathrm{O}_{2}$ (Battarbee, 1979). Oxidation byproducts and residual oxidant were removed by decanting distilled water rinses after material settled for a minimum of $24 \mathrm{~h}$. Cleaned material was resuspended in distilled water and allowed to settle onto $22 \mathrm{~mm}$ circular microscope cover glasses in Battarbee Chambers (Battarbee, 1979), then dried under controlled conditions. The dried material was then mounted in Hyrax. Voucher slides are retained in the Stoermer collection, housed at the Center for Great Lakes and Aquatic Sciences, University of Michigan.

Transects of the slides were scanned and dimensions of the first 30 complete (unbroken) valves of $S$. niagarae encountered were measured. Measurements included valve diameter, number of areolae in $10 \mu \mathrm{m}$, and total number of fascicles per valve. Areolae number was measured along a $10 \mu \mathrm{m}$ radius of valve commencing at the level of spine insertion and proceeding toward the valve center.

Dates reported follow the model of Schelske et al. (1988) which is based on ${ }^{210} \mathrm{~Pb}$ corrected for increased accumulation of organic and inorganic carbon in the upper sections of the core. The assumptions and rationale for this model are discussed extensively by Schelske et al. (1988). It should be noted that the newly calculated dates, which we believe more accurately represent the history of biogenic accumulation in Lake Ontario, vary from those originally reported by Stoermer et al. (1985a, 1985b).

\section{Results}

Figures 1-7 illustrate the range of size and valve morphology found in $S$. niagarae populations encountered in our samples. Specimens with both fine (Figs. 1-3) and robust (Figs. 4-6) morphology can be found throughout the size range of the species. Populations deposited prior to European occupation of the Lake Ontario basin are composed almost exclusively of specimens with robust structure. Finely structured valves become increasingly abundant in samples deposited after ca. 1840, and this trend accelerates after ca. 1947. Populations deposited after $c a$. 1955 are composed almost exclusively of fine morphs. The change in morphology is gradational, rather than absolute, and specimens with intermediate structure (Fig. 7) can be found in mid-core samples.

Figure 8 shows the relationship of average areolae number (per $10 \mu \mathrm{m}$ ) to sample depth. There appear to be four depth/date domains in the relationship. There is little trend in average areolae number of specimens from samples deposited between $c a$. 1720 and $c a$. 1844 [mean areolae no. $=11.0681+0.0082($ depth $(\mathrm{cm})) ; \mathrm{R}=0.31]$. Average number of areolae in samples deposited between $c a .1844$ and $c a .1938$ increases slightly [mean areolae no. $=12.5852-0.0432$ (depth $(\mathrm{cm})) ; \mathrm{R}=0.63$ ]. There is then a very rapid increase in average number of areolae in samples deposited between $c a .1947$ and $c a$. 1964. After stabilizing at over 14 in $10 \mu \mathrm{m}$, areolae numbers decline in the two most recent samples analyzed.

Figure 9 shows mean diameter of valves in the samples analyzed. Two date/depth domains are apparent. There is little trend in average diameter of valves in samples deposited between $c a .1720$ and ca. 1959 [average diameter $=63.216+$ 0.0041 (depth (cm)); $\mathrm{R}=0.02$ ]. There is con- 


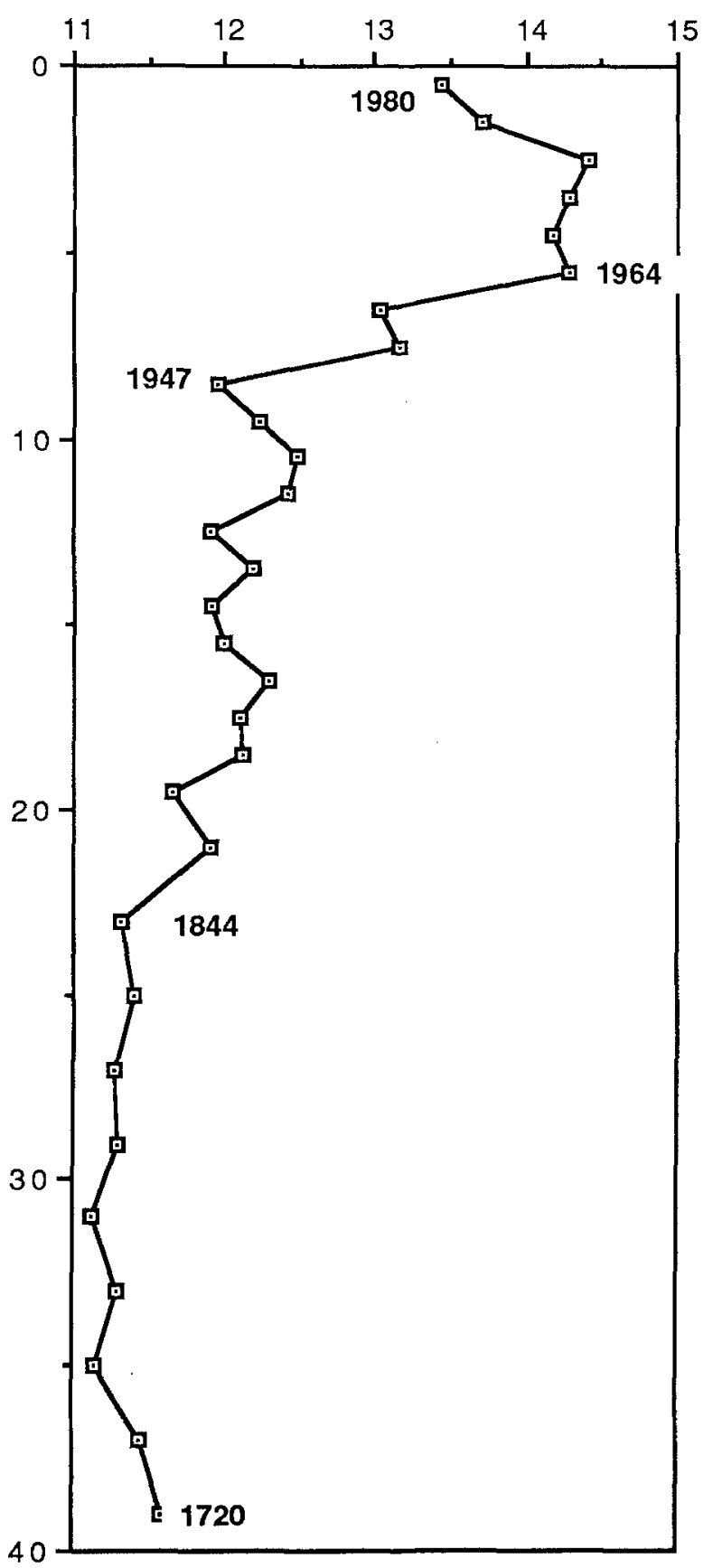

Fig. 8. Plot of mean number of areolae per $10 \mu \mathrm{m}$ in $S$. niagarae valves versus sediment depth $(\mathrm{cm})$ in core from Lake Ontario. Median date of material in sample ( $y r$ AD), based on ${ }^{210} \mathrm{~Pb}$, is shown at inflection points.

siderable sample-to-sample variation in mean diameter within this interval. Variation appears to be cyclic, and may result from periodic sexual

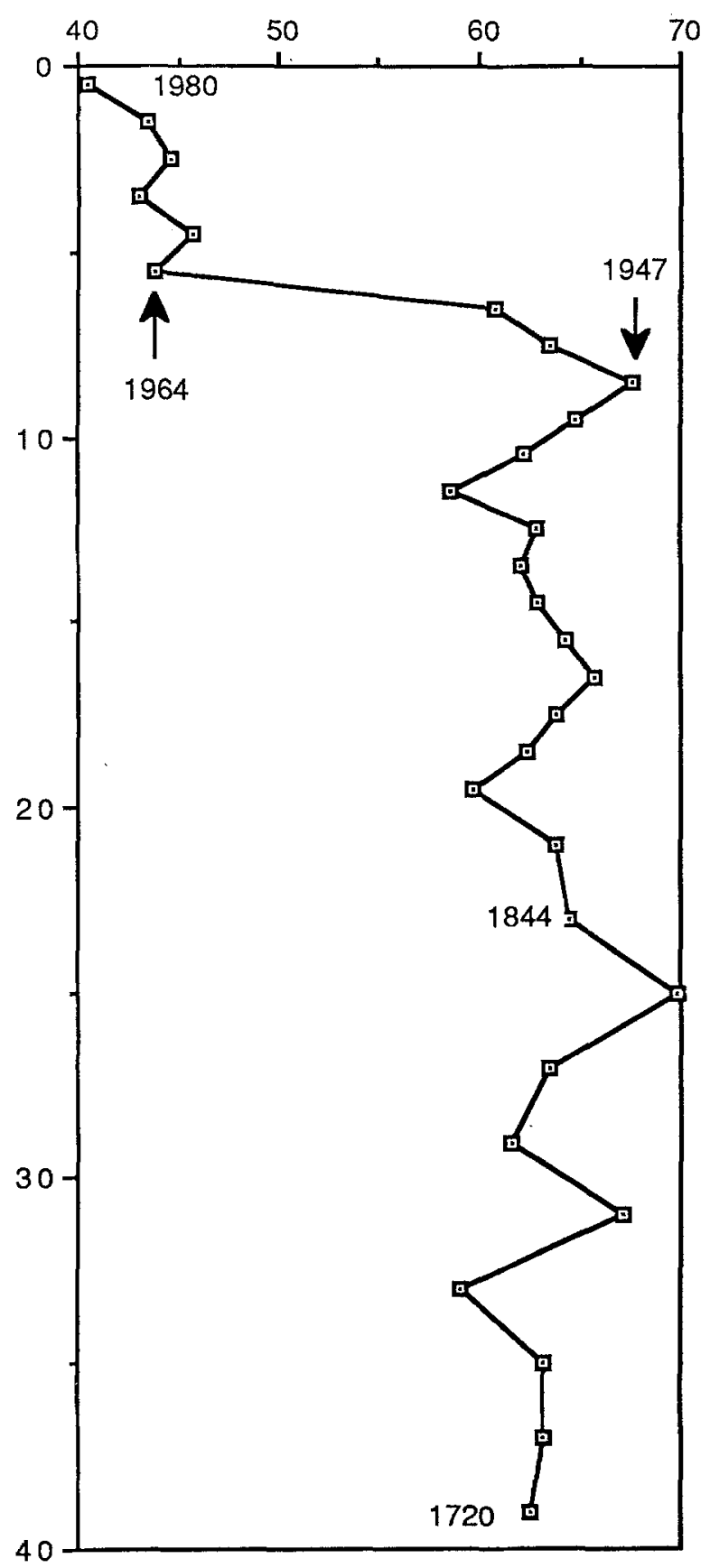

Fig. 9. Plot of mean diameter $(\mu \mathrm{m})$ of $S$. niagarae valves versus sediment depth $(\mathrm{cm})$ in core from Lake Ontario. Dates shown as in previous Figs.

reproduction by $S$. niagarae. Mean diameter of valves from samples deposited after ca. 1960 is much lower and less variable. 
Since density of structural elements of the valve is a partial function of valve diameter, we have also plotted areolae number per $10 \mu \mathrm{m}$ (Fig. 10)

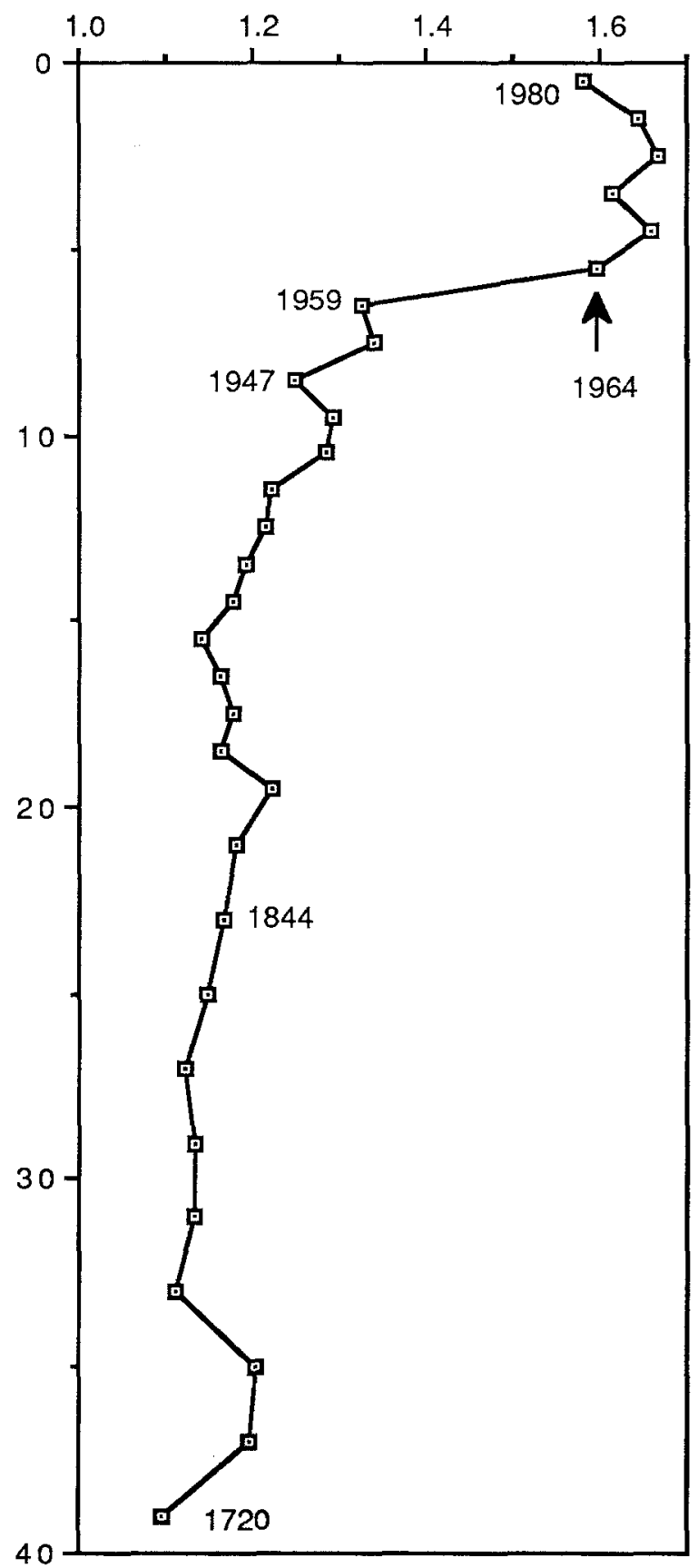

Fig. 10. Total number of fascicles per valve, normalized to mean valve diameter, for $S$. niagarae versus sediment depth $(\mathrm{cm})$ in core from Lake Ontario. Dates shown as in previous Figs. and total number of fascicles per valve (Fig. 11) divided by mean valve diameter. The main effect of normalization is to make trends in the upper

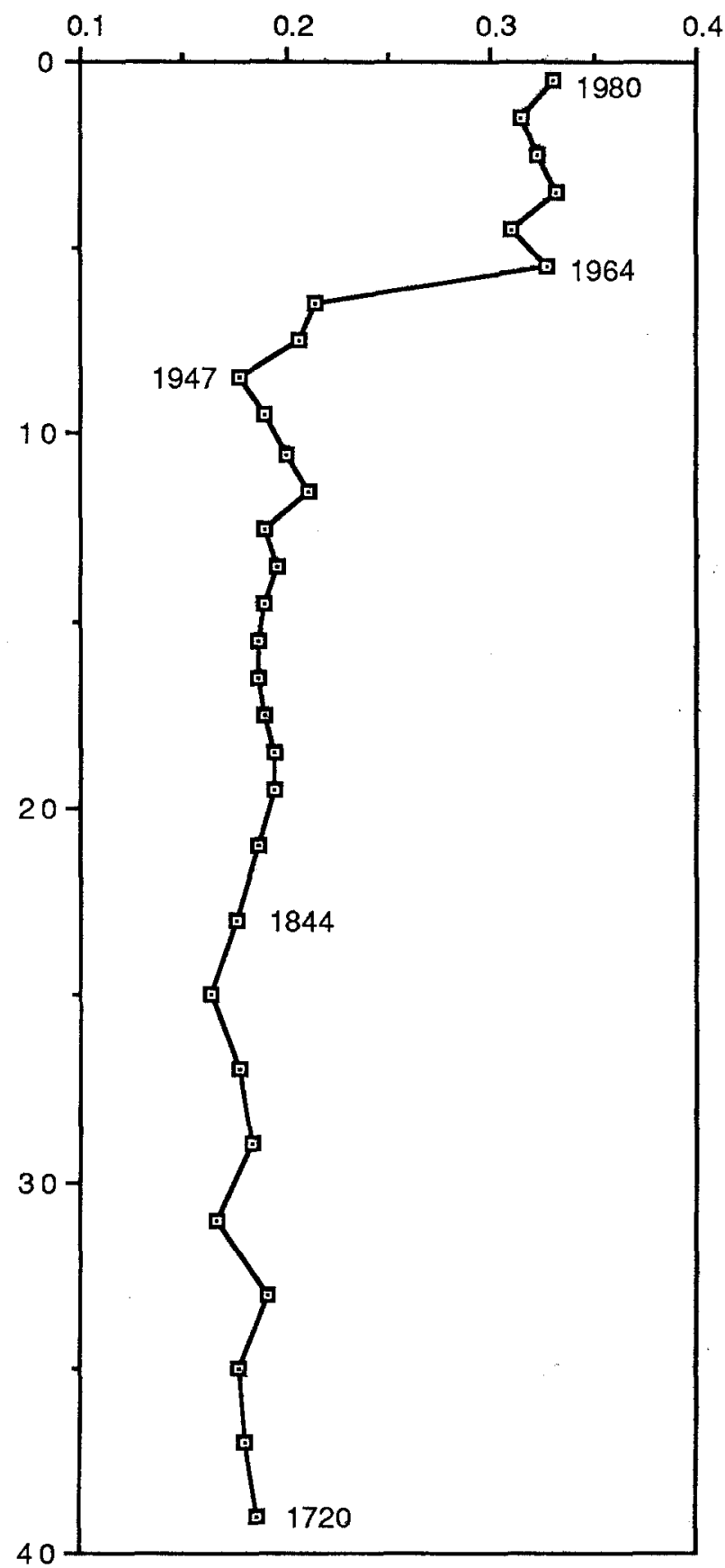

Fig. 11. Number of areolae in $10 \mu \mathrm{m}$, normalized to mean valve diameter, for $S$. niagarae versus sediment depth $(\mathrm{cm})$ in core from Lake Ontario. Dates shown as in previous Figs. 
section of the core more linear. The most unusual feature of these data is the high number of fascicles per unit diameter in samples from 34-36 and $36-38 \mathrm{~cm}$ depth. Review of the slides indicates that medium-sized valves with atypically narrow, sometimes uniseriate, fascicles were included in counts from both samples. Such specimens are present in other samples, but were not, by chance, included in populations analyzed. Since these apparently atypical valves are relatively rare in all samples, we cannot determine if they are truly more abundant in samples from 34-36 and $36-38 \mathrm{~cm}$ or if the observation results from a sampling artifact.

In Fig. 12 we have plotted mean valve diameter together with the maximum and minimum size of valves recorded in each subsample population analyzed. These do not necessarily include the absolute maximum and minimum size present in the total sample preparation. The minimum and maximum sizes recorded over all samples are $32 \mu \mathrm{m}$ and $101 \mu \mathrm{m}$, respectively. Note that most of the reduction in mean diameter in samples deposited after $c a .1964$ apparently resulted from loss of largest valves from the population. Also note that the minimum valve diameter recorded in all samples deposited after $c a .1964$ is near the minimum recorded in all earlier samples.

\section{Discussion}

It is apparent that either two mechanisms or two expressions of the same mechanism are responsible for the morphological variations in $S$. niagarae observed. The first results in an increase in the mean number of areolae and fascicles on the valve surface. The clearest expression is in the increase in radial areolae per linear measure. According to our data, the mechanism responsible is invoked soon following large scale European occupation of the Lake Ontario basin (ca. 1840), is grossly accelerated in the period from $c a .1947$ to $c a$. 1964 , and reaches a stable maximum thereafter. An increase in the number of fascicles normalized to valve diameter follows the same general pattern, but it is more difficult to determine where inflection points lie. It is clear that the number of fascicles per valve increases, particularly in the period after ca. 1900, and it is probable that this change results from the same mechanism driving

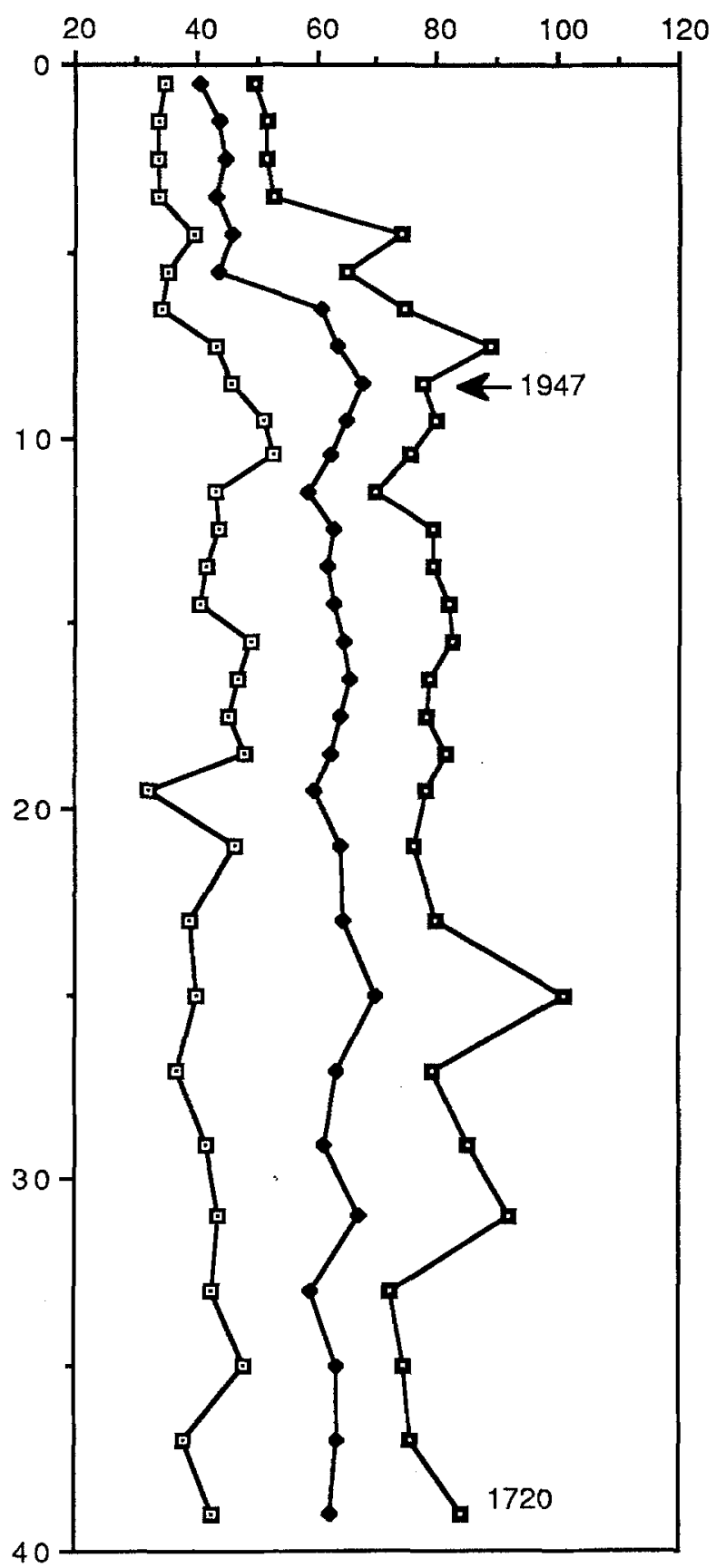

Fig. 12. Plot of mean diameter $(\mu \mathrm{m})$ of $S$. niagarae versus maximum and minimum valve diameter noted in each sample population. 
increase in areolae number. However, we are unable, on the basis of these data, to exclude the hypothesis that this trend is superimposed on a pre-existing trend toward reduced fascicle size.

We believe the most plausible explanation of observed trends in areolae and fascicle number is response of $S$. niagarae populations in Lake Ontario to changing ecological conditions in the lake. The modifications observed are consistent with those found in populations of this species from North American lakes of differing trophic status (Theriot \& Stoermer, 1984a). The direction and timing of change is also consistent with the history of eutrophication of Lake Ontario inferred from analysis of the total diatom flora preserved in its sediments (Stoermer et al., 1985a). The pattern of morphological modification in S. niagarae is also consistent with modifications of puncta structure in Melosira islandica observed from the same material (Stoermer et al., 1985b). In our opinion the most likely direct causal mechanism is reduction in available silicon concentration (Schelske \& Stoermer, 1971; Schelske et al., 1983, 1986).

The feature of morphometric trends in $S$. niagarae which is not consistent with previous observations is the sudden reduction in mean and maximum size of populations deposited after $c a$. 1959. This could be interpreted as evidence of a speciation event or the introduction of a different, but closely related species. However, this hypothesis is not supported by change in non size-related character states we have been able to discover. We feel that the more likely explanation is that conditions in Lake Ontario after $c a .1959$ no longer allowed $S$. niagarae to carry on sexual reproduction. Like most diatoms, S. niagarae undergoes size diminution as a result of asexual cell division and must undergo sexual reproduction in order to return to maximum size. Our hypothesis implies that populations which occurred in Lake Ontario after ca. 1959 were derived from Lake Erie. Although unable to complete their life cycle in Lake Ontario, they were able to continue asexual reproduction until they reached the minimum size limit for the species (Geitler, 1932) and perished. This would account for the observed complete loss of large cells, reduction in average size, and the fact that minimum size observed after $c a .1959$ was consistently at the minimum observed over all cases. It is also consistent with the observed lack of variability in valve size in samples deposited after the mid-1950's, since this is controlled by a species' sexual cycle, at least in some lakes (Nipkow, 1927). The hypothesis appears feasible in that ca. $70 \%$ of water entering Lake Ontario is directly derived from Lake Erie, and the mean residence time of water within Lake Ontario is only $c a .8$ yr. Previous studies have reported transport of algal populations or remains within and between lakes in the Great Lakes system. Wolin et al. (1988) found significant abundance of populations derived from eutrophic Saginaw Bay in the deep water sediments of oligotrophic Lake Huron. Stoermer et al. (1987) attributed occasional recent occurrences of Cyclotella species in Lake Erie to transport from Lake Huron and Keilty et al. (1988) presented additional evidence of such transport.

The factor or factors which caused failure of $S$. niagarae sexual reproduction in Lake Ontario are less certain. We suspect that $S$. niagarae may require more available silicon to initiate sexual reproduction than the minimum necessary to continue asexual division and that concentrations in Lake Ontario dropped below the former minimum. Both Lake Erie and Lake Ontario have undergone anthropogenic eutrophication resulting in considerable modification of their diatom floras (Stoermer et al., 1985a, 1987) but silica supplies to the two lakes differ. Lake Erie continuously receives relatively silica-rich water from Lake Huron and its western basin is shallow, permitting wind-induced mixing to entrain silica regenerated from bottom sediments during any period of the year. Although diatom growth may reduce instantaneous silica concentrations to limiting levels, resupply, particularly in the western basin of Lake Erie, is reasonably constant. Lake Ontario, in contrast, receives already silica-depleted water from Lake Erie and its main basin is relatively deep. Consequently, silica resupply is limited to winter circulation, stream 

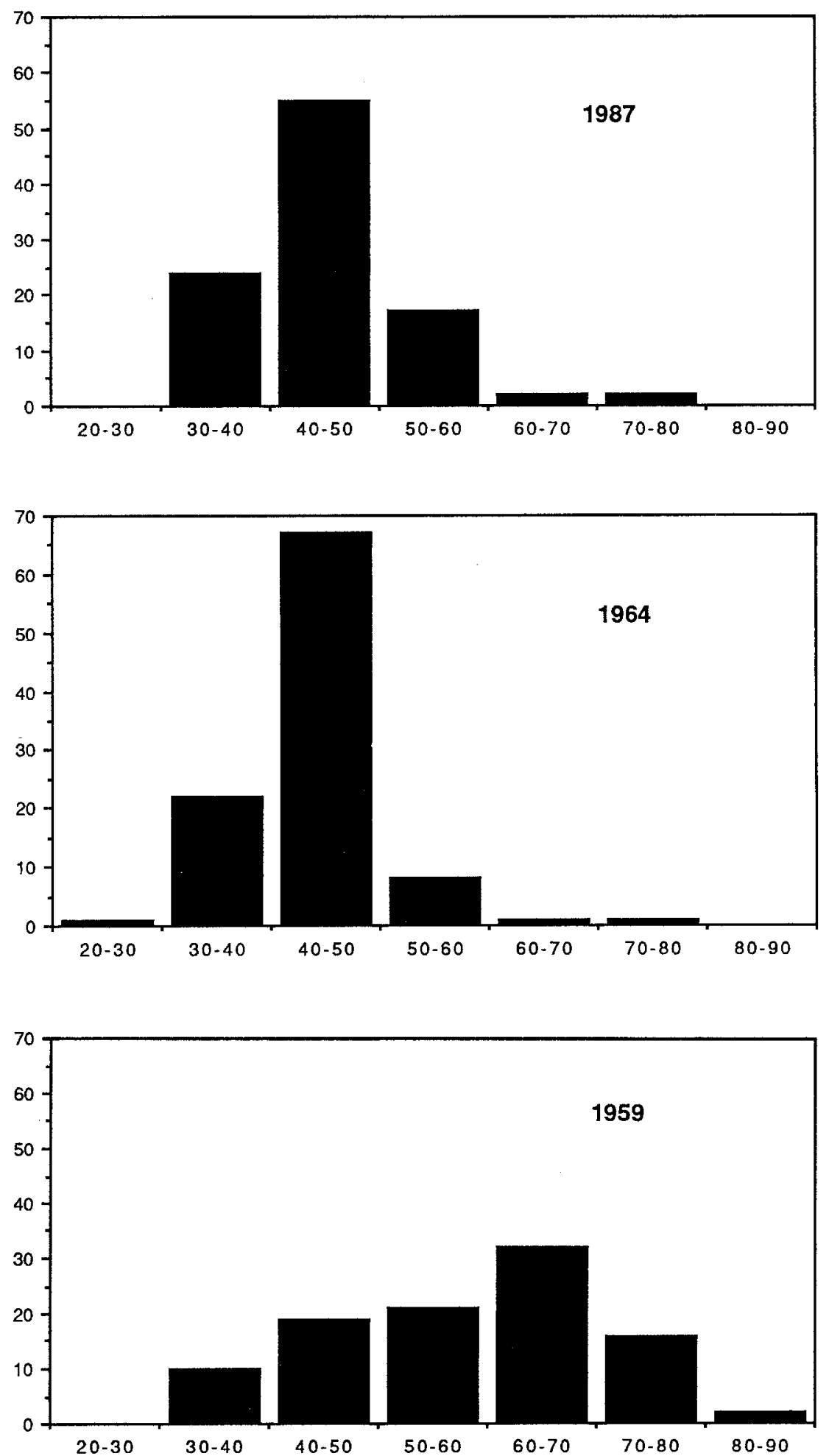

Fig. 13. Histograms of $S$. niagarae valve diameter ( $\mu \mathrm{m}-$ in $10 \mu \mathrm{m}$ categories) in sediments deposited in 1987 (upper panel), 1964 (middle panel), and 1959 (lower panel). 
inflows, and occasional summer upwellings. Thus, although both lakes are eutrophic, silica limitation is more stringent in Lake Ontario than in Lake Erie and it is plausible that diatom response in the two lakes should be different. However, it should also be noted that Lake Ontario is badly contaminated with toxic organic compounds, and it is possible that toxic effects, singly or in combination with altered nutrient ratios, caused reproductive failure.

Since considerable effort has been expended to reverse eutrophication in Lake Ontario, and there is convincing evidence that phosphorus concentrations have been reduced (Dobson, 1984; Schelske et al., 1988), it is of interest whether or not this change is reflected by $S$. niagarae morphology. In order to address this question, we analyzed the population present in the surficial (top $0.5 \mathrm{~cm}$ ) sediments of a core taken in 1987 . The results of this study do not provide convincing evidence that the factor or factors limiting sexual reproduction in $S$. niagarae have been reversed. The trend toward lower areolae numbers noted in the upper samples of our previous core (Fig. 8) has apparently continued, and mean number in the 1987 core is 12.7 in $10 \mu \mathrm{m}$, the lowest found in any sample deposited since $c a$. 1947. On the other hand, there is little evidence of increase in mean valve diameter and we did not note any valves in the post-auxospore size range (Fig. 13). It thus appears that recent conditions in Lake Ontario are conducive to more 'normal' vegetative frustule formation, but that sexual reproduction has not resumed.

Our observations should provide a cautionary note to paleoecologists working on connected lake systems. It appears entirely possible that transported populations may maintain asexual reproduction under conditions outside their normal ecological range. Failure to recognize such occurrences could lead to taxonomic and/or ecological misinterpretation. There is likely a greater potential for misinterpretation in the oceanic record. It is easy to envision scenarios where persistent current patterns could transport asexual populations to depositional areas far removed from conditions allowing completion of their full life cycle.

\section{Acknowledgements}

We thank Dr. R. Bourbonniere, Canada Centre for Inland Waters, Burlington, Ontario, for providing the material investigated. The study supported by Grant No. R-813831 from the Office of Exploratory Research, U.S. Environmental Protection Agency and Grant No. OCE-8614619 from the Marine Geology and Geophysics Program, U.S. National Science Foundation. Contribution No. 515 of the center for Great Lakes and Aquatic Sciences.

\section{References}

Battarbee, R. W., 1979. Diatoms in lake sediments. pp. 177-225. In: International Geological Correlation Programme project 158, Paleohydrological changes in the temperate zone in the last 15000 years. Subproject B, lake and mire environments project guide (B. E. Berglund, ed.). Dept. of Quaternary Geology, University of Lund, Lund, Sweden. 340 pp.

Cleve-Euler, A., 1951. Die Diatomeen von Schweden und Finnland. I. Centricae. K. Sven. Vet.-Akad. Handl., Fjärde Ser. 2: 1-162.

Dobson, H. F., 1984. Lake Ontario water chemistry atlas. Natl. Water Res. Inst., Canada Centre for Inland Waters, Burlington, Ontario, Sci. Ser. No. 139. 59 pp.

Ehrenberg, C. G., 1846. Neue Untersuchungen über das kleinste Leben als geologisches Moment. Mit kurzer Charakteristik von 10 neuen Genera und 66 neuen Arten. Ber. 1845 Bekannt. Verh. Königl. Preuss. Akad. Wiss. Berlin. 1845: 53-88.

Geitler, L., 1932. Der Formwechsel der pennaten Diatomeen (Kieselalgen). Arch. Protistenk. 78: 1-226.

Genkal, S. I. \& G. V. Kuzmin, 1979. Biometric analysis of the main structural elements of the valves in the species of the genus Stephanodiscus Ehr. (Bacillariophyta). Bot. Zhur. 64: 1237-1244. [in Russian].

Håkansson, H. \& S. Locker, 1981. Stephanodiscus Ehrenberg 1846 , a revision of the species described by Ehrenberg. Nova Hedwigia, Beih. 35: 117-150.

Keilty T. J., E. F. Stoermer \& D. S. White, 1988. Algal remains in some surface sediments of Lake Erie. J. Great Lakes Res. 14: 164-170.

Nipkow, F., 1927. Uber das verhalten der skelette planktischer Kieselalgen in geschichteten Tiefenschlamm des Zurich-und Baldeggersees. Schweiz. Z. Hydrobiol. 4: $11-120$.

Schelske, C. L. \& E. F. Stoermer, 1971. Eutrophication, silica depletion, and predicted changes in algal quality in Lake Michigan. Science 173: 423-424. 
Schelske, C. L., E. F. Stoermer, D. J. Conley, J. A. Robbins \& R. M. Glover, 1983. Early eutrophication in the lower Great Lakes: new evidence from biogenic silica in sediments. Science 222: 320-322.

Schelske, C. L., E. F. Stoermer, G. L. Fahnenstiel \& M. Haibach, 1986. Phosphorus enrichment, silica utilization, and biogeochemical silica depletion in the Great Lakes. Can. J. Fish. Aquat. Sci. 43: 407-415.

Schelske, C. L., J. A. Robbins, W. D. Gardner, D. J. Conley \& R. A. Bourbonniere. 1988. Sediment record of biogeochemical responses to anthropogenic perturbations of nutrient cycles in Lake Ontario. Can. J. Fish. Aquat. Sci. 45: 1291-1303.

Stoermer, E. F., J. A. Wolin, C. L. Schelske \& D. J. Conley, 1985a. An assessment of ecological changes during the recent history of Lake Ontario based on siliceous microfossils preserved in the sediments. J. Phycol. 21: 257-276.

Stoermer, E. F., J. A. Wolin, C. L. Schelske \& D. J. Conley, 1985b. Variations in Melosira islandica valve morphology related to eutrophication and silica depletion. Limnol. Oceanogr. 30: 414-418.

Stoermer, E. F., J. P. Kociolek, C. L. Schelske \& D. J. Conley, 1987. Quantitative analysis of siliceous micro- fossils in the sediments of Lake Erie's central basin. Diatom Res. 2: 113-134.

Theriot, E. C. \& E. F. Stoermer, 1984a. Principal components analysis of character variation in Stephanodiscus niagarae Ehrenb.: Morphological variation related to lake trophic status. pp.97-111. In: Proc. VIII ${ }^{\text {th }}$ Internat. Diatom Symp. (D. G. Mann, ed.). Otto Koeltz, Koenigstein.

Theriot, E. C. \& E. F. Stoermer, 1984b. Principal components analysis of Stephanodiscus: Observations on two new species from the Stephanodiscus niagarae complex. Bacillaria 7: 37-58.

Theriot, E. C. \& E. F. Stoermer, 1986. Morphological and ecological evidence for two varieties of the diatom Stephanodiscus niagarae. pp. 385-394. In: Proc. VII ${ }^{\text {th }}$ Internat. Diatom. Symp. (M. Richard, ed.). Otto Koeltz, Koenigstein.

Theriot, E. C., Y.-z. Qi, J.-r. Yang \& L.-y. Ling, 1988. Taxonomy of the diatom Stephanodiscus niagarae from a fossil deposit in Jingyu County, Jilin Province, China. Diatom Res. 3: 159-167.

Wolin, J. A., E. F. Stoermer, C. L. Schelske \& D. J. Conley, 1988. Siliceous microfossil succession in recent Lake Huron sediments. Arch. Hydrobiol. 114: 175-198. 